\title{
Discourse as the Form of Political Sciences (On the Example of the Republic of Kazakhstan)
}

Murat Orlenbaevich Nassimov ${ }^{1}$

Zhengisbek Muratbekuly Tolen²

Saltanat Zharylkasynovna Ibadullaeva ${ }^{3}$

Botagoz Zhapparovna Paridinova1

Yernar Opagaliyevich Ustagaliyev²

\begin{abstract}
1University «Bolashak», Abay avenue, 31, Kyzylorda, 120008, Kazakhstan; nasimov_m@mail.ru 2Suleyman Demirel University, Abylai Khan St. 1/1, Kaskelen, Almaty 040900 Kazakhstan ${ }^{3}$ Korkyt Ata Kyzylorda State University, Aiteke bie Street, 29 A, Kyzylorda, 120014, Kazakhstan
\end{abstract}

\section{Doi:10.5901/mjss.2015.v6n5s1p399}

\section{Abstract}

To research political discourse is the main problem of political science, including political linguistics. This concept is characterized between subjects, also specialists, who are engaged in the theory of sociology, social psychology; culture studies and mass communication are interested in it. So, we can research the political texts by the means of the present-day form of research, and thoroughly figure out public consciousness and socio-political questions. Discourse is considered as the form of political sciences in this article in the example of Sciences of the Republic of Kazakhstan.

Keywords: discourse, political communication, political linguistics, political philology.

\section{Introduction}

Any scientific theory must be very exact. We consider telling to indicate the full meaning of scientific terms correctly and to apply the results of studies. We are not mistaken if we say that exploring the main directions of the present political science era are figured out by political communication, or communications industry. Max Weber and Emile Durkheim's social direction identifying connection between society and the authorities; Seymour Martin Lipset's institutional direction considers arranging social life and combining permanent forms; Talcott Parsons' systematic functional direction considering policy as a system; Robert Merton's bureaucracy theories; Erich Fromm's psychological direction; F. Fukuyama's futurological direction; G. Almond and S. Verba and Samuel Phillips Huntington's comparative political science promote exploring political communication itself. Our examined question was conducted with the research explored according to the political communications.

General political communication is the process which goes from one part of the political system to the next one and it is between political and social systems. Western Scientists divide political communication into three main points, which goes to 1) through mass media; 2) managerial class and controlled 3) informal channels. All the aforesaid questions are of the significance in investigating the discourse problems.

Here political contacted relevance state and ideological form and development of Republic of Kazakhstan on the construction conditions of political discourse are discussed to the following reasons.

Firstly, political discourse obeyed not only the social content of the construction supply, also the ruling worldview and ideological paradigm. Therefore it is not possible not to watch his nation-building. Through this mutual connection the language of communication between the state and society is clarified.

Secondly, political discourse determines cultural process in a society, influenced by a large force of visibility and ability and defines language features of policy information distributing emergent values of the social consciousness. 


\section{Literature Review}

Netherlands scientific Teun A. van Dijk performed a lot of scientific works on political discourse issue (Teun, 2014). We think the works of scientists as F. Bayram (Bayram, 2010), Z.S. Harris (Harris, 1991) and C. Hart (Hart, 2005) should be taken into consideration. The Russian scientists as A.N. Baranov, O.V. Mikhailov, G.A. Satarov, E.A. Shipova (Baranov and etc, 2004), V.A. Maslova (Maslova, 2008), N.M. Perelgut, E.B. Suchotskaya (Perelgut, 2013) are working on this topic. One of the authors of the article M.O. Nassimov considered the given topic by political advertising (Nassimov, 2013) and political consulting (Nassimov, 2013) issues.

\section{Methods}

The bases of the research work are scientists' research works and information up a given issue. The article is about different conceptions discussing institutions and political processes comparatively and retrospectively and also systemicstructural, historic-philosophical and institutional analysis methods.

\section{Results and Discussion}

Researching topic is one of the phenomena we meet daily. The power struggle is the main theme of this sector and the relevance of the forward. More attention is paid to political language when its social life is brighter and more democratic. Not only professional politicians, journalists and political scientists pay attention to the political discourse, also common people give importance to it. Generally, political linguistics and political philology concepts are used together, though they have a lot of difference. For example, political linguistics is viewed through the actions considering minority concept of politics and clarifies the objects below: a) syntax, semantics and pragmatics of a political discourse; b) formulation and explanation samples of this discourse. Political philology involves relationships between concepts as "power", "influence", and "the concepts of authority" [Januschek, 1985].

Therefore political discourse is the main object of the political linguistics study. Linguistics and politology are two individual sciences convergence benefits have this linguistics industry shape up today's daily information era never lose relevance. The works of Russian scientists as A.G. Altunyan [Altunyan, 1999], M.R. Proskuryakov [Proskuryakov, 1999] and E.I. Sheigal [Sheigal, 2000] published in the mid 90-ies XX century defines development of political linguistics.

Kazakh language specialists, who made a theme relevant, B.A. Ahatova [Ahatova, 2006] and K.O. Esenova's [Esenova, 2007] works that are performed in the Kazakh science are very important. According to K.O. Esenova's abstract of dissertation on doctorate scientific degree 10.02.02 - Kazakh language specialty philology science recess: "In any official publication political issue is widely covered comparing of culture, health care, science, education and sports. Because the whole society life is directly linked with this political atmosphere, entire social and etc. relations are regulated through policy. In connection with this political discourse news are on the main surface of a newspaper daily" [Esenova, 2007].

In addition to that a scientist suggests following opinion to an aforesaid question: "The term discourse analysis was penetrated to the science by Zellig Harris (1952) and it was initially used relating advertising. Then in XX century in1970's discourse analysis concerned traditional linguistics appeared in the works of American and European scientists. Fundamental scientific works intended aforesaid problem were published in 80-90's. The concept discourse became significant because of specialized branches of an anthropocentric way in linguistics as psycholinguistics, sociolinguistics, paralinguistic, neurolinguistics, cognitive linguistics and pragmalinguistics and etc. Aforesaid branches were not only classified inherently and also piled up around discourse concept. In connection with it we cannot give a full and exact explanation to a discourse up to date. In our opinion, while analyzing discourse pragmatically we should take into consideration communicative situation and its participants relating extra linguistic and ethno-cultural factors, also we should control communicant's intention and goal. Reading any information the one tries to imagine the author's dreamworld while preparing to represent it. In other words, understanding discourse means go in other person's thinking the world freely or involuntarily. By turn addresser uses all semantic resources of a language to make it in a proper way".

L.A. Kochetova says that these pragmatic signs indicate discourse features: target explicit social attempt; conditions of a situation (discourse participants, their roles in it, then communicative interaction and etc.); values, strategy, genre" [Esenova, 2007].

Consequently, according to the opinions above it is proved scientifically that political linguistics of the domestic political science is being researched, also the mutual connection between political sciences is pleased. Therefore, we think both of the sciences will work on researching the language of a policy in future. 
Key features of a common policy language or political language from ordinary words:

"political lexicon" is terminated and "political" language of signs are not often in use;

own peculiarity structure of a discourse is the most characteristic linguistic method;

discourse feature that runs - sound or it is made in writing [Bayley, 1985]. The history of a term "political language" started earlier, from 1789, it was used widely [Demyankov, 2002].

Russian scientist E.I. Sheygal's point of view: "a content of any talk falls on the political structure is a policy discourse" [Sheigal, 2000]. A.N. Baranov on to argue: "A political discourse participant or concrete political communication theme forming is a discursive amount of experience" [Baranov, 2001]. According to Ya.A. Sorokin's reference: 'Political discourse is another form of an ideological discourse. If the political discourse is a short pragmatic concept, from ideological pragmatic it is artificial... First form of a discourse is a sub discourse, second is meta discourse [Sorokin, 1997].

In our opinion, political discourse defines spiritual and ideological view of a society and it is a concept of today's political sciences which shows differences between political point of view and world outlook of a certain time.

Interest in researching common political texts can be explained by several factors. Firstly, to make intra linguistic necessities, which were directed to different historical stages and language systems. Secondly, political questions and mutual political nature of a political thinking; samples to create the forecast in a policy, political texts on the mass media and necessity of preparing analyzing methods of political texts. Thirdly, to try to separate political communication from public opinion manipulation [Baranov, 2001].

There is an abundant factor of singular questions in Kazakhstan of a research topic. Firstly, mostly citizens with higher education understand the notions that apply to political term in our country. Most people do not understand the concepts of political kinds of information on the periodic surfaces of the press. Therefore, it is important to identify the political literacy of residents in our country and thoroughly improving the literacy rate. Second, people living in the vast region of our state differ in mentality, talking and values. This brings us to perceive political information differently. Thirdly, an initial version of common political information needs to be prepared for people in Russian, then in the Kazakh language.

Political discourse can be considered in three different views:

1. philological;

2. socio psycholinguistic;

3. individual hermeneutical [Bell, 1994].

We think that given scientific branches should be worked out.

Experts point out the following forms of political discourse:

- institutional political discourse - politicians, the texts (parliament shorthand record, political documents, political leaders'speech and interviews in meetings), which are applied to the policy of political communication;

- mass media political discourse - texts spread through the press, television, radio and Internet by journalists;

- official business-related political discourse - dense contacted text communication system, which was aimed to civil servants apparatus;

- $\quad$ texts of "ordinary citizen", not an experienced political party communications politician or a journalist. Various letters and suggestions, which have been a politician or government agencies aimed row, the letters declared in mass media;

- "political detectives", "political poetry" and "political memoirs" that were widely distributed to the present day;

- scientific texts of communication about policy.

\section{Conclusion}

Selecting the above issues, we notice that words in use are changing every day. Let us suppose, Soviet Union rules never come back and in current globalization era international concept come to memorize in our consciousness. The concept "revolution" appeared in last years of the Soviet Union and "democracy" is a basic concept formed with a value and the concept had formed newly independent country. In domestic political science terminology we started using western categories and institutes as "political consulting", "political imageology", "political management", "political marketing", "political publicity" and etc.

Common discourse categories significance in political science was investigated in this work. We can figure out the details of a basic political purpose of the information by looking at the above mentioned opinion. Firstly, it is shifting public's gaze to the information; secondly, get people's interest by explaining the content of the message, in a result it is absorbed deeply in the consciousness of a society; thirdly, to be conceived through the need and intention to connect the 
linking through thought with the given information; the fourth, on this basis of information to form a system acts to emphasize harmony in our country.

\section{Acknowledgment}

Given research work was carried out at the state grants circle Ministry of Education and Science of the Republic of Kazakhstan "Distinguished professor of a Higher education - 2014".

\section{References}

Teun, A. van Dijk. Discourse and Knowledge. A Sociocognitive Approach. Cambridge: Cambridge University Press, 2014. - 407 p.

Bayram, F. Ideology and political discourse: a critical discourse analysis of Erdogan's political speech. ARECLS, 2010, Vol.7: P. $23-40$.

Harris, Z.S. A Theory of Language and Information: A mathematical approach. Oxford \& New York: Clarendon Press, 1991. xii, 428 pp.; illustr.

Hart, C. Analysing political discourse: Toward a cognitive approach. Critical Discourse Studies, 2005, 2 (2): P. 189-194.

Baranov, A.N., Mikhailov, O.V, Satarov, G.A., Shipova, E.A. Political discourse: methods of the analysis of topic structure and metaphorics. M.: INDEM foundation, 2004. - $94 \mathrm{p}$.

Maslova, V.A. Political discourse: language games or games in words? Political linguistics, 2008. Issue. 1(24): P. 43-48.

Perelgut, N.M., Sukhotskaya, E.B. On the structure of political discourse. The Bulletin Of Nizhnevartovsk State University, 2013, 2: P. 35-41.

Nassimov, M.O., Kaldybai, K., Paridinova, B.Zh. Features of Political Advertisement in the Republic of Kazakhstan. MEJSR, 2013, 14 (8): P. 1129-1134.

Nassimov, M.O., Dosmanbetov, D.B., Dosmanbetova, S.B., Paridinova, B.Zh., Ensepov, A.A. Political consulting: essence, specifics, technologies. Life Sci J, 2013, 10(4): P. 2866-2869.

Januschek, F. Politische Sprachwissenschaft: Zur Analyse von Sprache als kultureller Praxis. Opladen: Westdeutscher Verlag, 1985. P. 6.

Altunyan, A.G. From Bulgarin to Zhirinovsky. Ideologically stylistic analysis of political texts. M.: Russian State Univercity for the Humanities, 1999. - $263 \mathrm{p}$.

Proskuryakov, M.R. Fight discourse: Sketch of language of elections. MSU Vestnik. Series 9. Philology, 1999, 1: - P. 34-49.

Sheigal, E.I. Semiotics of a political discourse. Volgograd, 2000. - $368 \mathrm{p}$.

Ahatova, B.A. Political discourse and language consciousness. Almaty: Ecomomics, 2006. - 302 p.

Esenova, K.O. Pragmatics modern Kazakh media text (on the basis of materials of the Kazakh press): abstract of dissertation on doctorate scientific degree 10.02.02 - Kazakh language specialty philology science. Institute of Linguistics for the name of A.Baitursynov, 2007. $-49 \mathrm{p}$.

Bayley, P. Live oratory in the television age: The language of formal speeches // G. Ragazzini, D.R.B.P. Miller eds. Campaign language: Language, image, myth in the U.S. presidential elections 1984. - Bologna: Cooperativa Libraria Universitaria Editrice Bologna, 1985. - P. 77-174.

Demyankov, V.Z. Political discourse as subject of politological philology. Political science. Political discourse: History and modern researches. 2002. 3: P. 32-43.

Baranov, A.N. Introduction to applied linguistics. M., 2001. - P. 246.

Sorokin, Ya.A. Political discourse: attempt of interpretation of concept // Political discourse in Russia. M., 1997. - P. 57.

Bell, V. Negotiation in the workplace: The view from a political linguist // A. Firth ed. The discourse of negotiation: Studies of language in the workplace. Oxford etc.: Pergamon, 1994. - P. 46. 